\title{
PENGARUH PERMAINAN BOLA TEMBAK TERHADAP POWER OTOT TUNGKAI SISWA SD Tarsad
}

\begin{abstract}
ABSTRAK
Tujuan dari penelitian ini adalah untuk memperoleh informasi tentang pengaruh permainan bola tembak terhadap power otot tungkai siswa putri kelas IV SDN.Metode penelitian yang digunakan adalah metode eksperimen. Populasi penelitian adalah siswa putri kelas IV SD dengan sampel sebanyak 20 orang yang ditentukan dengan teknik random sampling.

Berdasarkan hasil pengolahan data dengan uji statistik, ternyata secara empirik permainan bola tembak berpengaruh secara signifikan (berarti) terhadap power otot tungkai siswa putri kelas IV. Berdasar pada hasil penelitian tersebut di atas, penulis mengajukan beberapa saran sebagai berikut. Para guru sebagai pengelola pembelajaran di sekolah hendaknya guru selalu kreatif mencari teknik pembelajaran yang paling tepat digunakan dalam, misalnya dengan mencoba teknik pembelajaran yang sesuai dengan karakteristik siswa. Permainan merupakan salah satu teknik pembelajaran yang sesuai dengan karakteristik siswa yang sedang berada pada tahap senang bermain.
\end{abstract}

Kata Kunci: Permainan Bola Tembak, Power Otot Tungkai, Siswa Putri SD.

\section{A. Pendahuluan}

Salah satu tujuan pendidikan jasmani (Penjas) di sekolah dasar berdasarkan kurikulum 2004 (2004:3), adalah “Mengembangkan keterampilan pengelolaan diri dalam upaya pengembangan dan pemeliharaan kebugaran jasmani serta pola hidup sehat melalui berbagai aktivitas jasmani”. Sejalan dengan tujuan tersebut, salah satu fungsi penjas pada aspek organik adalah meningkatkan kekuatan otot, yaitu jumlah tenaga maksimum yang dikeluarkan oleh otot atau kelompok otot.

Kekuatan otot merupakan salah satu kebugaran jasmani sebagaimana dikemukakan Badriah (2002: 22) bahwa, "Sesuai dengan sistem tubuh, komponen kebugaran jasmani meliputi kekuatan otot, kelentukan, daya tahan kardiorespirasi dan daya tahan otot, kecepatan,kelincahan, keseimbangan, kecepatan reaksi dan koordinasi, serta memiliki komposisi tubuh yang ideal”. 
Sejalan dengan tujuan dan fungsi Penjas sebagaimana dikemukakan di atas, standar kompetensi untuk aktivitas pengembangan di kelas IV sekolah dasar berdasarkan Kurikulum 2004 adalah "Melakukan latihan yang lebih kompleks untuk meningkatkan kekuatan, kelenturan, dan keseimbangan dan memiliki pengetahuan/ konsep serta nilai-nilai yang terkandung di dalamnya” (Depdiknas 2003: 12). Kompetensi dasarnya adalah melakukan keterampilan yang lebih kompleks untuk meningkatkan kekuatan, kelenturan, dan keseimbangan. Yang termasuk ke dalam kekuatan yang dimaksud di sini salah satunya adalah kekuatan otot. Jika otot sudah memiliki kekuatan, maka akan timbul kemampuan sekelompok otot melakukan kontraksi secara eksplosif dalam waktu yang sangat singkat. Menurut Badriah (2002: 24) "kekuatan otot adalah kemampuan otot atau sekelompok otot melakukan kontraksi secara eksplosif dalam waktu yang sangat singkat disebut power”. Dari penjelasan mengenai power tersebut, maka latihan untuk meningkatkan power diperlukan bentuk latihan yang khusus yang didasari adanya gerakan eksplosif. Oleh karena itu materi pokok untuk kompetensi dasar tadi adalah latihan pengembangan komponen kebugaran jasmani, khususnya power.

Power merupakan salah satu komponen kebugaran jasmani yang diperlukan dalam banyak cabang olahraga seperti karate, sepak bola, bola voli, renang dan masih banyak cabang olahraga yang lainnya. Hal ini sejalan dengan pendapat Harsono (1988: 200) bahwa,

Power terutama penting untuk cabang-cabang olahraga di mana atlet harus mengerahkan tenaga yang eksplosif seperti nomor-nomor lempar dalam atletik dan melempar bola softboll. Juga dalam cabang-cabang olahraga yang mengharuskan atlet untuk menolak dengan kaki, seperti nomor-nomor lompat dalam atletik, sprint, voli (untuk smes), dan nomor-nomor yang ada unsur akselerasi (percepatan) seperti balap lari, balap sepeda, mendayung, renang, dan sebagainya.

Misalnya, power otot tungkai memegang peranan penting dalam cabang olahraga seperti sepak bola untuk melaksanakan teknik menendang, atletik untuk nomor-nomor lari dan lompat, dan bola voli untuk melakukan block, spike, dan sebagainya. 
Bertolak dari pernyataan di atas, penulis beranggapan bahwa power otot tungkai perlu ditingkatkan melalui latihan yang sistematis, berulang-ulang, dan over load. Bentuk latihan untuk meningkatkan power tungkai sama dengan bentuk latihan untuk meningkatkan power otot-otot lainnya yaitu dengan latihan beban. Selain dengan latihan beban power juga bisa ditingkatkan dengan latihan pliometrik.

Berdasar pada latar belakang masalah di atas, penulis merumuskan masalah penelitian ini sebagai berikut. "Bagaimana pengaruh permainan bola tembak terhadap power tungkai siswa putri kelas IV?”. Sesuai dengan rumusan masalah di atas tujuan penelitian ini untuk mengetahui pengaruh permainan bola tembak terhadap power tungkai siswa putri kelas IV SD.

\section{B. Tinjauan Pustaka}

\section{Pengertian Permainan}

Banyak ahli yang mengemukakan pengertian tentang permainan. Menurut Azis (2000:1.4), “Permainan adalah suatu kegiatan yang menarik, menantang, dan yang menimbulkan kesenangan yang unik, baik dilakukan oleh seorang ataupun lebih, yang dilakukan oleh anak-anak atau orang dewasa, tua atau muda, orang miskin atau kaya, laki-laki atau perempuan”. Berdasarkan Kamus Besar Bahasa Indonesia Edisi 2001 (Pusat Bahasa, 2001: 698), salah satu makna kata "permainan adalah hal bermain: perbuatan bermain: misalnya pada kalimat Permainan bulu tangkis sangat digemari masayarakat”. Pontjoputro, dkk. (1999: 1.7) mengemukakan tentang permainan menurut pendapat tiga orang ahli sebagai berikut.

1. Menurut Herbert Spencer, "Permainan dapat menyalurkan tenaga yang berlebihan yang ada pada anak".

2. Menurut Lazarus, "Permainan adalah keasikan yang bukan dalam bentuk pekerjaan dan bermaksud untuk bersenang-senang serta istirahat”.

3. Menurut Stanley Hall, "Permainan anak itu adalah ulangan dari pada kehidupan nenek moyangnya”.

Pontjoputro, dkk.(1999:1.3) menyatakan "Permainan merupakan cabang olahraga yang kita gunakan sebagai alat dalam usaha pendidikan. Tiap kali kita 
menggunakan suatu alat pasti kita mengharapkan kegunaan alat itu dalam usaha kita untuk mencapai tujuan”.

Dari pendapat-pendapat ahli di atas dapat disimpulkan bahwa permainan itu merupakan suatu kegiatan yang menarik, menantang, dan menimbulkan kesenangan, atau perbuatan bermain. Dengan demikian istilah permainan itu tidak dapat dipisahkan dari istilah bermain, karena orang yang sedang melakukan kegiatan permainan disebut sedang bermain. Istilah bermain oleh Wardani (2000: 1.2) diartikan sebagai “aktivitas yang hanya bertujuan untuk mendapatkan kesenangan”. Lee dalam Pontjopoetro, dkk. (1998: 1.3) melihat bermain merupakan suatu faktor yang mempengaruhi perkembangan tiap individu. Menurut Pontjoputro, dkk. (1999: 1.4), “Bermain adalah latihan untuk dapat hidup sebagai manusia”.

Jika dikaji secara seksama pengertian istilah bermain menurut ketiga ahli di atas dan jika kita hubungkan dengan pengertian permainan, maka dapat ditarik kesimpulan sebagai berikut.

a. Permainan dapat menyalurkan kelebihan tenaga yang ada dalam tubuh terutama anak yang sedang dalam masa pertumbuhan dan perkembangan.

b. Permainan merupakan alat untuk menikmati kesenangan dan berekreasi, disamping mempererat hubungan sesama teman terutama dalam hubungan keluarga dan kerja.

c. Permainan anak itu merupakan ulangan perbuatan nenek moyangnya, seperti yang tampak pada permainan anak sesuai dengan perkembangannya. Pada masamasa tertentu anak senang melakukan permainan sebagai pemburu, petani, pedagang, permainan membuat rumah, jalan-jalan, dan sebagainya.

d. Permainan selalu diiringi oleh gerakan jasmani dan gerakan (getaran) jiwa, maka permainan dapat memberikan pengalaman berbagai macam gerak bagi anak, sehingga mereka menguasai berbagai macam gerak tersebut.

e. Bermain adalah bergerak sambil bersenang-senang. Karena itu permainan dapat mempertahankan dan meningkatkan kebugaran jasmani.

Dari paparan di atas tampak jelas bahwa permainan itu merupakan suatu kebutuhan hidup sehari-hari sebagaimana kebutuhan akan makan dan minum yang dapat merangsang pertumbuhan serta perkembangan jasmani dan rohani.

Jenis permainan itu banyak sekali macamnya tergantung dari mana kita melihatnya. Jenis permainan dapat digolongkan berdasarkan jenis alat yang 
digunakannya, besar kecilnya alta atau bola yang dipergunakan, siapa pelaksana dari permainan itu, bahkan ada juga yang berdasarkan organisasi atau peraturan yang dipergunakan, dan lain sebagainya.

Azis (2000: 1.6) mengelompokkan jenis permainan sebagai berikut.

a. Pengelompokan permainan berdasarkan jumlah pemain

1) permainan beregu,

2) permainan perorangan, dan

3) permainan pasangan/ganda

b. Pengelompokan permainan berdasarkan sifat permainan

1) permainan untuk mengembangkan fantasi,

2) permainan untuk mengembangkan kemampuan berpikir,

3) permainan kreasi seni, dan

4) permainan untuk mengembangkan aspek fisik (kekuatan, ketahanan, kelincahan, kebangsan, reaksi, dan lain-lain).

c. Pengelompokan permainan berdasarkan alat yang dipakai

1) tanpa alat, dan

2) dengan alat (bola dan selain bola)

d. Pengelompokkan permainan berdasarkan bolanya yang dipakai

1) Permainan bola besar dan

2) Pernmainan bola kecil

e. Pengelompokkan permainan berdasarkan permainan dengan alat selain bola

1) Permainan dengan alat balok,

2) Permainan dengan alat tongkat,

3) Permainan dengan alat tali pendek,

4) Permainan dengan alat tali panjang,

5) Permainan dengan alat simpai,

6) Permainan dengan alat ganda,

7) Permainan dengan alat saputangan/selendang, dan

8) Permainan dengan alat balon dan lain-lain

\section{Permainan Bagi Anak Sekolah Dasar}

Perlu diingat bahwa setiap anak didik mempunyai daya penerimaan yang berbeda dalam mempelajari suatu keterampilan motorik. Mereka mempunyi tingkatan kemampuan motorik dan tingkatan belajar motorik yang berbeda. Tingkatan ini ditentukan oleh tingkat karakteristik anak didik itu sendiri, dan kemampuannya. 
Aziz (2000: 3\& 4.7) mengelompokkan permainan anak dalam beberapa kelompok, yaitu: "1) permainan imajinasi (permainan dengan cerita, dengan meniru), 2) permainan tanpa alat, 3) permainan dengan alat (memakai alat bola, dan alat yang bukan bola”.

Sesuai dengan permasalahan penelitian ini, permainan yang diterapkan dalam penelitian ini adalah permainan dengan alat (memakai bola) yaitu permainan bola tembak. Untuk lebih jelasnya penulis kemukakan pada subbab khusus yaitu konsep permainan bola tembak.

\section{Konsep Permainan Bola Tembak}

Permainan bola tembak adalah permainan yang mengharuskan penembak melakukan tembakan ke arah kaki yang menjadi sasaran tembak dengan menggunakan bola tenis. Sasaran (kaki) yang ditembak dibatasi hanya dari bagian lutut ke bawah. Pemain yang menjadi sasaran tembak harus berusaha menghindar dengan cara melompat agar tidak kena tembak.

Dalam permainan ini, pemain yang menjadi sasaran tembak berdiri di dalam lingkaran atau kotak yang berdiameter 1 meter. Pemain yang menjadi penembak berdiri di luar lingkaran atau kotak tempat sasaran tembak dengan jarak $3 \mathrm{~m}$ dari lingkaran atau kotak tempat sasaran tembak. Berdasarkan sifatnya permainan bola tembak termasuk ke dalam kelompok permainan yang bertujuan untuk mengembangkan aspek fisik (kekuatan, ketahanan, kelincahan, kebangsan, reaksi, dan lain-lain).

Aspek fisik yang dapat dikembangkan melalui permainan bola tembak adalah power otot tungkai, kelincahan dan koordinasi mata dan tangan. Peningkatan power otot tungkai akan diperoleh pada saat menghindar dari tembakan si penembak dengan cara meloncat secara berulang-ulang dengan cepat. Sedangkan kelincahan akan diperoleh pada saat mengubah arah atau posisi tubuh untuk menghindar dari tembakan sedangkan koordinasi mata dan kaki akan terlatih pada saat menangkap bola dan melempar bola. 
a. Prinsip permainan bola tembak. Dalam permainan bola tembak, si penembak harus berusaha untuk menembak kaki sasaran tembak dari batas lutut ke bawah yang berada di lingkaran atau kotak yang berdiameter 1 meter dan yang ditembak berusaha menghindari lemparan si penembak dengan cara melompat dengan cepat.

b. Peraturan Permainan Bola Tembak. Peraturan permainan bola tembak dalam penelitian ini penulis buat sebagai berikut:

1) Jumlah pemain bola tembak bisa tiga orang sampai 5 orang.

2) Orang yang menjadi sasaran tembak dilakukan dengan undian atau ditunjuk oleh guru.

3) Pergantian orang tembak bisa ditentukan dengan waktu atau dengan jumlah perkenaan tembakan. Dengan waktu orang yang menjadi sasaran tembak baru di ganti setelah 60 detik atau 120 detik dan dihitung berapa kali kena selama waktu tersebut, siswa yang sedikit kenanya dinyatakan sebagai pemenang sedangkan dengan jumlah perkenaan misalnya tiga kali kena baru diganti maka orang yang paling lama bisa bertahan dinyatakan pemenang.

4) Bola yang digunakan bola tenis sebanyak 4 buah

5) Tembakan dinyatakan sah apabila kena bagian lutut sampai kaki.

6) Penembak harus berurutan pada saat menembak misalnya pemain 3 orang(2orang penembak) maka tidak boleh melakukan tembakan bersamaan artinya penembak yang satu lagi baru menembak setelah sasaran tembak mendarat lagi baru bisa menembak.

7) Jarak tembak antara 2-3 meter dan sasaran tembak berada pada lingkaran yang berdiameter 1 meter atau segi empat.

\section{Pengertian Power}

Pengertian power menutur para ahli adalah sebagai berikut menurut Noer (1996: 140) "kemampuan otot atau segerombolan otot untuk melawan beban/tahan dengan kecepatan tinggi dalam suatu gerakan”. Suhendro (2001: 4.5) “ adalah kemampuan otot atau sekelompk otot untuk mengatasi tahan beban dengan kecepatan yang sangat tingi dalam suatu gerakan yang utuh, misalnya gerakan melompat”. Harsono (2001: 24) “power adalah kemampuan otot untuk mengerahkan kekuatan maksimal dalam waktu yang amat singkat”. Badriah (2002:24) mengemukakan bahwa, "Power adalah kemampuan otot atau sekelompok otot melakukan kontraksi secara eksplosif dalam waktu yang sangat singkat”. Dari pengertian di atas, terlihat 
bahwa kekuatan dan kecepatan merupakan unsur penting dalam power. Selanjutnya Badriah (2002:24) menjelaskan bahwa, "Daya ledak otot dipengaruhi oleh: kekuatan dan kecepatan kontraksi otot”.

Power berperan penting untuk cabang-cabang olahraga seperti yang dikemukakan Harsono (1988: 200) "Power terutama penting untuk cabang-cabang olahraga di mana atlet harus mengerahkan tenaga yang eksplosif seperti nomornomor lempar dalam atletik dan melempar bola soft ball. Juga dalam cabang - cabang olahraga yang mengharuskan atlet untuk menolak dengan kaki”.

Menurut Suharno (1993: 59) "penggunaan power adalah: 1) Untuk mencapai prestasi maksimal, 2) dapat mengembangkan taktik bertanding dengan tempo cepat dan gerak mendadak, 3) memantapkan mental bertanding atlet, dan 4) simpanan tenaga anaerobik cukup besar".

Selain untuk atlet power juga penting dalam kehidupan sehari-hari seperti yang dikemukakan Badriah (2002: 24) "dalam kehidupan sehari-hari daya ledak otot dibutuhkan dalam upaya: memindahkan tubuh sebagian atau keseluruhan pada tempat lain secara tiba-tiba”.

Baik tidaknya power seseorang menurut Suharno (1993: 59) ditentukan oleh beberapa faktor. faktor-faktor tersebut adalah:

a. Banyak sedikitnya macam fibril otot putih (phasic) dari atlet.

b. Kekuatan dan kecepatan otot atlet rumus $\mathrm{P}=\mathrm{F} \times \mathrm{V}, \mathrm{P}=$ power, $\mathrm{F}=$ Force, dan $\mathrm{V}$ = Vecolity.

c. Waktu rangsangan maksimal 34 detik, misalnya waktu rangsangan hanya 15 detik, power akan lebih baik dibandingkan dengan waktu rangsangan selama 34 detik.

d. koordinasi gerakan yang harmonis antara kekuatan dan kecepatan

e. tergantung banyak sedikitnya zat kimia dalam otot (ATP)

f. penguasaan teknik gerak yang benar.

Latihan power yang baik harus memenuhi persyaratan sebagai ciri latihan explosive power. Ciri latihan explosive power menurut Suharno (1993: 60) adalah sebagai berikut. 
a. Melawan beban relatif ringan, berat badan sendiri, dapat pula tambahan beban luar yang ringan.

b. Gerakan latihan aktif, dinamis dan cepat.

c. Gerakan-gerakan merupakan satu gerak yang singkat, serasi dan utuh.

d. Bentuk gerak bisa cyclic maupun acyclic.

e. Intensitas kerja sub maksimal atau maksimal.

Menurut Harsono (2001: 23) latihan untuk meningkatkan power bisa dilakukan dengan cara “ a) Rentang repetisi antara latihan 12-15 RM; kemudian setelah 10-12 kali dilanjutkan dengan cara kedua yaitu b) Beban kira-kira 50\% , diangkat secapatcepatnya tanpa henti sebanyak sekitar 15 kali”. Selain dengan bentuk latihan tersebut Harsono (2001:35) “selain dengan latihan beban khususnya untuk meningkatkan kekuatan dan power otot-otot, metode latihan yang lebih mengarah kepada pengembangan power/daya ledak adalah metode latihan yang disebut pliometrik (plyometries)”.

Sesuai dengan masalah yang penulis teliti, penulis hanya membahas pengaruh permainan bola tembak terhadap peningkatan power tungkai. Karena karakteristik dari permainan bola tembak tersebut menyerupai latihan pliometrik maka penulis akan mengemukakan prinsip-prinsip latihan pliometrik yang dikemukakan Harsono (2001:42) sebagai berikut:

1. makin cepat dan makin jauh otot diregangkan (misalnya waktu jongkok), makin besar energi kosentrik (concentric force) yang dihasilkan usai peregangan tersebut. Maka hasilnya ialah gerakan yang lebih kuat (forceful) untuk mengatasi beban (inertia dari obyek), baik beban itu tubuh kita sendiri maupun beban eksternal (tolak peluru, mengangkat beban, mem-blok zandzak, dsb).

2. gerakan setelah tahap pra-regang harus dilakukan secara eksplosif, serta sesegera dan semulus mungkin.

3. kekerapan lompatan (rate) dan tingginya melakukan lompatan lebih penting daripada jauhnya lompatan.

4. gerakannya harus dilakukan secra maksimal

5. bila menggunakan bangku untuk dilompati, mulailah dengan bangku yang tingginya tidak lebih dari $30 \mathrm{~cm}$.

6. prinsip overload harus diterapkan.

7. intensitas latihan harus diterapkan. 
8. permukaan (surface) untuk melompat sebaiknya yang empuk (rumput, matras dari karet). Guna melindungi anggota-anggota badan bagian bawah dari kemungkinan cedera.

9. elastisitas otot penting untuk menghasilkan"potensial elastic energy"

10. sesuai dengan sistem energi yang digunakan, tujuan latihan pliometrik bukanlah untuk melatih aerobik. Latihan pliometrik adalah murni latihan anaerobik yang menggunakan energi kreatin fosfat. Karena itu istirahat antara set jangan terlalu singkat.

\section{Metode Penelitian}

Untuk membuktikan hipotesis yang penulis ajukan, penulis melakukan penelitian dengan menggunakan metode eksperimen, yaitu mengadakan percobaan menerapkan suatu bentuk latihan. Penulis memilih metode eksperimen dalam penelitian ini berdasar pada pertimbangan bahwa tujuan penelitian ini adalah untuk mengetahui suatu hasil yang diujicobakan, yaitu pengaruh permainan bola tembak terhadap power tungkai.

Desain penelitian dalam penelitian ini adalah pretest-postes desaign seperti bagan di bawah ini.

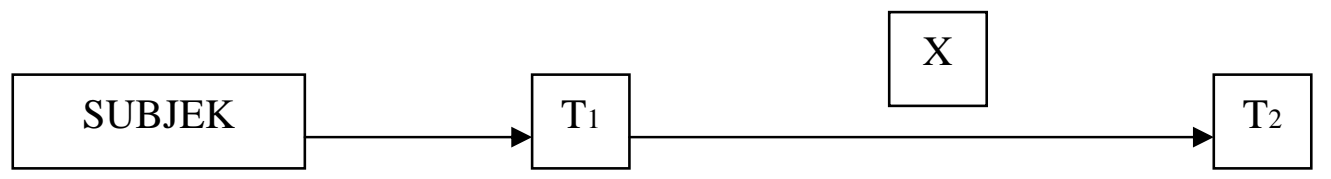

Gambar 1. Desain Penelitian Eksperimen

Keterangan :

$\mathrm{T}_{1} \quad$ = Tes awal (tes vertical jump) untuk mengukur power tungkai sebelum diberi perlakuan berupa permainan bola tembak.

$\mathrm{T}_{2}=$ Tes akhir (tes vertical jump) untuk mengukur power tungkai setelah diberi perlakuan berupa permainan bola tembak.

$\mathrm{X}=$ Permainan bola tembak.

Untuk memperoleh data penelitian tersebut peneliti menggunakan instrumen penelitian yang sesuai dengan permasalahan yang dibahasnya. Instrumen penelitian yang dipergunakan dalam penelitian ini adalah tes yang digunakan untuk mengukur power tungkai waktu melompat ke atas yang biasa disebut Vertical Power Jump. Reliabilitas tes tersebut 0,977 dan validitasnya 0,989. 


\section{Hasil Penelitian dan Pembahasan}

Sesuai dengan prosedur pengolahan data dan langkah-langkah penghitungannya dilampirkan pada daftar lampiran, maka hasil pengolahan data diuraikan pada bagian berikut.

1. Hasil penghitungan skor rata-rata (mean) standar deviasi dan varians dari tes awal dan tes akhir yang hasilnya dapat dilihat pada Tabel 4.1 di bawah ini.

Tabel 1

Hasil Penghitungan Skor Rata-rata, Standar Deviasi, dan Varians dari setiap Tes

\begin{tabular}{|c|c|c|c|}
\hline Variabel Tes & Rata-rata & Standar Deviasi & Varians \\
\hline Tes Awal & 28,9 & 3,1 & 9,1 \\
\hline Tes Akhir & 44,0 & 7,0 & 49,00 \\
\hline
\end{tabular}

2. Hasil Pengujian normalitas data dengan menggunakan rumus uji normalitas data melalui pendekatan uji $\chi^{2}$ (chi-kuadrat). Hasilnya dapat dilihat pada Tabel 4.2 di bawah ini.

Tabel 2

Hasil Penghitungan Normalitas Data dari Setiap Tes

\begin{tabular}{|c|c|c|c|}
\hline Variabel Tes & Nilai $\chi_{\text {hitung }}^{2}$ & $\chi^{2}{ }_{0,95(k-3)}$ & Kesimpulan \\
\hline Tes Awal & 2,93 & 5,99 & Normal \\
\hline Tes Akhir & 2,14 & 5,99 & Normal \\
\hline
\end{tabular}


3. Hasil Penghitungan Homogenitas.

Untuk mengetahui homogen tidaknya sampel yang akan diteliti, maka homogenitas sampel penelitian perlu dihitung terlebih dahulu. Hasil penghitungan homogenitas sampel, dapat dilihat pada Tabel 4.3 di bawah ini.

Tabel 3

Hasil Pengujian Homogenitas

\begin{tabular}{|c|c|c|l|}
\hline $\begin{array}{c}\text { Variabel } \\
\text { Tes }\end{array}$ & Nilai $F_{\text {hitung }}$ & $F_{\text {tabel }(\alpha=0,05) d k=(30,30)}$ & Kesimpulan \\
\hline $\begin{array}{l}\text { Tes Awal } \\
\text { Tes Akhir }\end{array}$ & 5,10 & 2,12 & Homogen \\
\hline
\end{tabular}

4. Pengujian Hipotesis

Untuk membuktikan kebenaran dari hipotesis, maka penulis menggunakan uji kesamaan dua rata-rata uji satu pihak dengan menggunakan uji $t$ '. Dalam hal ini perlu dirumuskan hipotesis nol (Ho) yaitu "Tidak terdapat pengaruh yang signifikan permainan bola tembak terhadap power otot tungkai siswa putri kelas IV SD. Hasil penghitungan tersebut dapat dilihat pada Tabel 4.4 di bawah ini.

\section{Tabel 4}

Hasil Pengujian Hipotesis

\begin{tabular}{|c|c|c|c|}
\hline Variabel Tes & $t_{\text {-hitung }}^{\prime}$ & $t_{\text {-tabel }}^{\prime} \alpha=0,95$ & Kesimpulan \\
\hline $\left.\begin{array}{l}\text { TesAwal } \\
\text { TesAkhir }\end{array}\right\}$ & 8,83 & 1,73 & Signifikan \\
\hline
\end{tabular}

Kriteria pengujian hipotesis adalah terima hipotesis (Ho) apabila $t^{\prime} \leq 1,73$ dan tolak hipotesis jika $t^{\prime}>1,73$. Berdasarkan tabel tersebut di atas ternyata $t^{\prime}{ }_{\text {hitung }}>$ dari $t_{\text {tabel }}$ dan berada di luar daerah penerimaan hipotesis. Dengan demikian hipotesis (Ho) ditolak pada taraf nyata $\alpha=0,05$. Ini berarti “Terdapat pengaruh yang 
signifikan permainan bola tembak terhadap power otot tungkai siswa putri kelas IV SD.”

Adanya peningkatan power otot tungkai siswa putri kelas IV SD Karsamenak ini disebabkan oleh hal-hal sebagai berikut.

1. Power menurut Harsono (2001: 35) “selain dengan latihan beban yang khusus untuk meningkatkan kekuatan dan power otot-otot, metode latihan yang mengarah kepada pengembangan power/daya ledak adalah metode latihan yang disebut pliometrik (plyometrics).

2. Power tungkai yang baik akan memberi pengaruh terhadap gerakan-gerakan aktivitas fisik dalam cabang olahraga apa pun. Permainan bola tembak mempunyai karakteristik yang sama dengan latihan pliometrik karena permainan bola tembak diawali dengan meregangkan terlebih dahulu otot-otot semaksimal mungkin ke arah yang berlawanan pada otot yang akan dilatih sebelum mengkontraksikan atau memendekkan otot-otot itu secara eksplosif dalam waktu yang cepat.

3. Permainan bola tembak yang dilakukan secara baik dan benar menurut prinsip latihan pliometrik akan menjamin efektivitas dan efisiensi terhadap peningkatan power tungkai. Menurut Harsono (1999: 35) prinsip latihan pliometrik adalah 1) gerakan dilakukan secara eksplosif; 2) Kekerapan (rate) melakukan lompatan lebih penting daripada jauhnya lompatan.; 3) prinsip over load dan intensitas harus diterapkan untuk menjamin perkembangan power.

4. Pada prinsipnya, permainan bola tembak akan menimbulkan motivasi pada anak untuk melakukan latihan dan tidak membuat anak cepat jenuh sehingga tidak cepat lelah karena ada motivasi ekstrinsik berupa kemenangan. Oleh karena itu permainan bola tembak dapat diterapkan dalam pelatihan yang bertujuan meningkatkan power otot tungkai.

5. Dalam permainan bola tembak pelaku sasaran tembak akan meloncat ke depan, ke samping, meloncat setinggi-tingginya untuk menghindar dari tembakan bola dari pelaku tembak baik dengan satu kaki maupun dua kaki. Pada saat menolak ke 
depan otot tungkai melakukan kontraksi dengan melawan beban sendiri untuk menghasilkan loncatan yang jauh atau loncatan yang tinggi. Dipandang dari karakteristik tersebut, maka akan terbentuk kekuatan otot tungkai sebagai dasar terbentuknya power tungkai. Dengan demikian maka aspek kekuatan dan kecepatan sebagai dasar terjadinya power meningkat sehinga memungkinkan pula power tungkai semakin meningkat.

\section{DAFTAR PUSTAKA}

Badriah, Dewi L.B. 2002. Fisiologi Olahraga. Bandung: Pustaka Ramadhan. Depdiknas. 2003. Kurikulum Berbasis Kompetensi. Jakarta: Pusat Kurikulum.

Harsono. 1988. Coaching dan Aspek-aspek Psikologis dalam Coaching. Jakarta: CV Tambak Kusuma

Harsono. 2001. Latihan Kondisi Fisik. Jakarta: Pusat Ilmu Olahraga KONI Pusat

Pontjopoetro, Soetoto, dkk. 1999. Permainan Anak Tradisional dan Aktivitas Ritmik. Jakarta: Iniversitas Terbuka.

Pusat Bahasa Depdiknas .2001. Kamus Besar Bahasa Indonesia . Jakarta: Balai Pustaka.

Suharno. 1993. Metodologi Pelatihan. Jakarta: Sekum PP PBVSI

Surachmad, Winarno. 1987. Pengantar Penelitian Ilmiah, Dasar Metodik. Bandung: Tarsito.

Wardani. 2000. Permainan Kecil. Jakarta: Universitas Terbuka.

\section{BIODATA}

Tarsad adalah dosen pada Universitas Negeri Medan. Penulis menyelesaikan pendidikan pada jenjang doktor (S-3) dari Universitas Negeri Jakarta. 